\title{
POLA ASUH PEREMPUAN YANG BERSTATUS SINGLE PARENT PADA PENDIDIKAN ANAK (STUDI KASUS PEREMPUAN BERSTATUS SINGLE PARENT DI PASURUAN)
}

\author{
Oleh: Khoirun Nafidatul Muniro \\ Pasca Sarjana Pendidikan Bahasa Inggris UIN Malang
}

\begin{abstract}
A family is as a basic means of education toward children's growth process. In onther words, children education in family, basically, is an educational process of growth and competence as well as performance from birth. In this context, a family plays an important role as a significant basic education for an upcoming education system. However, how does a case of woman partially live as a single parent functioning her educational system? In this context, a writer does research on what Islamic concepts of a family education are. Empirically and methodologically, how are educational systems supposed to be developed in a family education?; And how is the influence of a woman-single parent's educational system to her children based on gender perspective?
\end{abstract}

\section{A. Pendahuluan}

Pendidikan dalam Islam memperoleh tempat dan posisi yang sangat tinggi, karena melalui pendidikan orang dapat memperoleh ilmu, dan dengan ilmu orang dapat mengenal tuhannya, mencapai ma'rifatullah. Pendidikan dalam Islam dipahami sebagai sebuah proses transformasi dan internalisasi nilai-nilai ajaran Islam terhadap peserta didik, melalui proses pengembangan fitrah, agar memperoleh keseimbangan hidup dalam semua aspeknya ${ }^{1}$. Dalam hal ini, fungsi pendidikan dalam Islam pada hakekatnya adalah proses pewarisan nilai-nilai budaya Islam untuk mengembangkan potensi manusia, dan sekaligus proses produksi nilainilai budaya Islam baru sebagai hasil interaksi potensi dengan lingkungan dan konteks zamannya. Oleh karena itu kunci keberhasilan umat Islam, agar mampu menangkap ruh ajaran Islam yang sesungguhnya dan selalu konteks dengan kehidupan tiada lain adalah melalui proses pendidikan. Fazlur Rahman mengatakan bahwa setiap reformasi dan pembaharuan dalam Islam harus dimulai dengan pendidikan². Mastuhu juga berpendapat bahwa manusia adalah makhluk yang memiliki daya akal dan kehidupan, maka ia harus membentuk peradaban dan memajukan kehidupan melalui proses pendidikan ${ }^{3}$.

\footnotetext{
${ }^{1}$ Muhaimin dkk, Pemikiran Pendidikan Islam, Trigenda Karya, Bandung 1993, Hal. 136

${ }^{2}$ Fazlur Rahman, Islam, Terj. Ahsin Muhammad, Bandung, Pustaka, 1984, 36-37

${ }^{3}$ Mastuhu, Dinamika Sistem Pendidikan Pesantren , Jakarta, INIS, 1994, Hal. 1
} 
Betapa pentingnya pendidikan itu sehingga harus dilakukan secara terus-menerus oleh manusia sampai akhir hayatnya. Islam telah memberikan konsep tentang pendidikan seumur hidup jauh sebelum lahirnya konsepsi tentang "pendidikan luar sekolah" dengan lifeeducation-nya ${ }^{4}$. Dalam sebuah hadits telah dijelaskan bahwa proses pendidikan tersebut harus dilakukan sejak anak dilahirkan (min al-mahdi) sampai ia meninggal (ila al-lahdi). Lebih jauh lagi jika kita menganalisa sebuah ayat Al-qur'an, mengisyaratkan bahwa proses pendidikan telah dilakukan sejak dari periode "yurjaun" (periode ketika manusia dibangkitkan kembali) Hal tersebut mengisyaratkan bahwa kehidupan manusia adalah merupakan sebuah proses kontinuitas antar periode yang masing-masing periode mempunyai implikasi kausalitas. Oleh karena itu, pendidikan itu berlangsung seumur hidup, maka prosesnya dapat dilakukan dalam keluarga, masyarakat, lemabaga-lembaga formal dan non-formal.

Pendidikan keluarga merupakan bagian dari jalur pendidikan sekolah yang diselenggarakan dalam keluarga, dan memberikan keyakinan agama, nilai budaya, nilai moral dan keterampilan. Jika kita kaji lebih dalam, maka pendidikan dalam keluarga merupakan pendidikan utama dan pertama, artinya bahwa pendidikan pertama kali dan yang memberikan arti terhadap perkembangan dan prestasi anak adalah pendidikan dalam keluarga. Mengingat demikian penting dan strategisnya pendidikan dalam keluarga, orang tua secara kodrati bertanggung jawab sepenuhnya terhadap anaknya yang mana harus semaksimal mungkin mendidik anaknya menuju pertumbuhan dan perkembangan fitrahnya. Kesalahan dalam pendidikan anak tersebut akan berakibat negatif, yakni si anak dapat menyimpang dari fitrah (nature) dan potensi kebaikannya berubah menjadi menjadi manusia yang berkualitas rendah.

Terkait dengan penjelasan di atas, penulis di sini berpijak pada pendidikan di dalam keluarga sebagai sarana basic education. Dan secara umum, keluarga dianggap sebagai elemen sistem sosial yang mana akan membentuk sebuah masyarakat. Sekurang-kurangnya keluarga terdiri dari ayah, ibu, dan anak sedangkan apabila dalam satu keluarga tidak ada ibu atau ayah, maka mereka disebut single parent. Padahal, semua orang menghendaki kasih sayang dan pendidikan dalam keluarga yang harmonis dan utuh. Tapi bagaimana dalam kasus perempuan yang berstatus single parent sebagai bentuk keluarga yang tidak utuh dalam menfasilitasi basic education bagi anak? Dalam konteks ini, penulis berusaha menelusuri bagaimana konsepsi Islam tentang pendidikan dalam keluarga. Dan secara empirismetodologis, bagaimana pola asuh yang perlu dikembangkan dalam pendididikan di keluarga? Serta bagaimana pengaruh pola asuh itu sendiri terhadap anak yang diasuh orang tua

\footnotetext{
${ }^{4}$ Soelaiman Joesoef, Pendidikan Luar Sekolah, CV. Usaha Nasional, Surabaya, 1979, Hal.17

${ }^{5}$ Qs. Al-A'raf, ayat 172 ,
} 
tunggal ditinjau dari perspektif gender? Sederetan pertanyaan di atas menyibak fakta disekeliling kita, tidak menutup kemungkinan terjadinya perceraian, meninggalnya suami, kekerasan dalam rumah tangga dan lain sebagainya yang mendorong perempuan memilih hidup sendiri dan berperan ganda dalam menjalankan tugasnya sebagai ibu dan pencari nafkah.

\section{B. Konsepsi IslamTentang Pendidikan Keluarga}

Dalam Islam, keluarga dikenal dengan istilah usrah, nasl, 'ali, dan nasb. Keluarga dapat diperoleh melalui keturunan, perkawinan, persusuan dan pemerdekaan ${ }^{6}$. Dalam pandangan antropologi, keluarga adalah suatu kesatuan sosial terkecil yang dimiliki oleh manusia sebagai makhluk sosial yang memiliki tempat tinggal dan ditandai oleh kerja sama ekonomi, berkembang, mendidik, melindungi, merawat, dan sebagainya, sedangkan inti keluarga adalah ayah, ibu, dan anak ${ }^{7}$.

Pendidikan dalam keluarga merupakan pendidikan pertama dan utama dimana orang tua menjadi pendidiknya yang paling bertanggung jawab terhadap perkembangan anaknya. Kaidah ini ditetapkan secara kodrati, karena mereka ditakdirkan menjadi wali dari anak yang dilahirkan tersebut dalam keadaan bagaimanapun mereka harus menempati posisinya itu yaitu orang yang paling bertanggung jawab dalam pendidikan anaknya itu. Sementara itu dalam alqur'an juga disinyalir adanya do'a anak kepada tuhan untuk kebahagiaan orang tuanya, yang di dalamnya terbawa serta tinggi rendah tingkat intensitas dan kesungguhan usaha pendidikan oleh orang tua untuk si anak (Ya Tuhanku, rohmatilah keduanya sebagaimana mereka telah mendidikku diwaktu kecil ${ }^{8}$. Dalam doa itu secara tidak langsung diajarkan bahwa permohonan si anak kepada tuhan bagi kebahagiaan orang tua itu dikaitkan dengan kualitas dan tingkat intesitas pendidikan yang telah diberikan kepadanya di waktu kecil.

Secara sederhana, kewajiban orang tua hanyalah mengembangkan apa yang secara primordial sudah ada pada anak, yaitu nature kebaikannya sendiri sesuai dengan fitrahnya. Tetapi di sisi lain orang tua juga mempunyai peranan menentukan dan memikul beban tanggung jawab utama jika sampai terjadi si anak menyimpang dari nature dan potensi kebaikannya itu sehingga menjadi manusia dengan ciri-ciri kualitas rendah. Inilah salah satu makna sebuah hadits yang amat terkenal yang menegaskan bahwa setiap anak dilahirkan

\footnotetext{
${ }^{6}$ Muhaimin dkk, Pemikiran Pendidikan Islam, trigenda Karya, Bandung, 1993, Hal. 289

${ }^{7}$ Wahyu, wawasan ilmu social dasar, Surabaya, Usaha Nasional, 1986, Hal. 57

${ }^{8}$ Q.S Al-Isra: 24
} 
dalam fitrah (nature, kesucian), kemudian ibu bapaknya-lah yang berkemungkinan membuatnya menyimpang dari fitrah itu.

\section{Anak dalam asuhan orang tua tunggal (single parent) ditinjau dari perspektif Gender}

Berdasarkan kamus bahasa Indonesia Single Parent secara empiris bermakna orang tua tunggal sedangkan secara terminologis bermakna orang tua tunggal yang mendidik dan mencukupi kebutuhan anak secara mandiri. Menurut hasil penelitian penulis di Pasuruan, single parent yang kerap kali terjadi di masyarakat kita dikarenakan oleh perceraian, dan ditinggal mati suami ${ }^{9}$. Jika ditinjau dari perspektif gender, faktor yang ditinggal mati suami kiranya merupakan sunnatulah sedangkan faktor perceraian merupakan rendahnya kualitas relasi gender yang ditujukan kepada keduanya (suami istri) dan kurang optimalnya fungsi keluarga dalam mencapai sakinah mawaddah wa rahmah sehingga dalam hal ini anak-anak akhirnya menjadi korban ${ }^{10}$.

Menurut analisis gender, tujuan perkawinan akan tercapai jika didalam keluarga tersebut dibangun atas dasar berkesetaraan dan berkeadilan gender. Kesetaraan dan keadilan gender merupakan kondisi dinamis, dimana laki-laki dan perempuan sama-sama memiliki hak, kewajiban, peranan, dan kesempatan yang dilandasi oleh saling menghormati, menghargai, dan bantu-membantu di berbagai sektor kehidupan. Untuk mengetahui apakah laki-laki dan perempuan dalam keluarga telah setara dan berkeadilan, kita dapat melihat pada hal-hal berikut:

1. Seberapa besar partisipasi aktif perempuan baik dalam perumusan dan pengambilan keputusan atau perencanaan maupun dalam pelaksanaan segala kegiatan keluarga baik dalam wilayah domestik maupun publik;

2. seberapa besar manfaat yang diperoleh perempuan dari hasil pelaksanaan berbagai kegiatan baik sebagai pelaku maupun sebagai pemanfaat dan pengikat hasilnya, khususnya dalam relasi keluarga; dan

3. seberapa besar akses dan kontrol serta penguasaan perempuan dalam berbagai sumber daya manusia maupun sumber daya alam yang menjadi aset keluarga, seperti hak

\footnotetext{
${ }^{9}$ Hasil penelitian yang dilakukan penulis selama 20 hari terhitung 3-23 Agustus 2007

${ }^{10}$ Mufidah Cholil, Paradigma Gender, Malang: Bayu Media, 2004, Hal 73-76
} 
waris, hak memperoleh pendidikan dan pengetahuan, jaminan kesehatan, hak-hak reproduksi, dan sebagainya ${ }^{11}$.

Menyadari pentingnya relasi gender dalam upaya meningkatkan keadilan gender, dewasa ini, fokus penanganannya tidak hanya melibatkan perempuan (istri), tetapi lebih ditujukan kepada keduanya (suami istri) yang kemudian dikenal relasi gender ${ }^{12}$. Dari relasi yang berkeadilan gender, peran-peran komunitas antara keduanya bermunculan yang dapat dilakukan sepanjang tidak melampaui kodrat kedua baik peran domestik maupun peran publik misalnya merawat dan mendidik anak, mengerjakan pekerjaan rumah tangga, mencari nafkah, pengambilan keputusan, dan sebagainya.

Selain rendahnya kualitas relasi gender sebagai akibat terjadinya single parent, masyarakat kita masih belum mampu mencerna arti pernikahan sebagai perjanjian sakral (mitsaqan ghalidha) antara suami dan istri. Perjanjian sakral itu, merupakan prinsip universal yang terdapat dalam semua tradisi keagamaan. Dengan itu pula, pernikahan dapat menuju terbentuknya rumah tangga yang sakinah. Untuk menuju kepada sakinah, terdapat tali pengikat yang dikaruniakan oleh Allah kepada suami istri setelah melalui perjanjian sakral, yaitu berupa mawaddah, rahmah, dan amanah ${ }^{13}$.

Mawaddah berarti kelapangan dan kekosongan dari kehendak buruk yang datang setelah terjadinya akad nikah. Rahmah adalah kondisi psikologis yang mucul di dalam hati akibat menyaksikan ketidakberdayaan. Karena itu, suami istri selalu berupaya memperoleh kebaikan pasangannya dan menolak segala apa yang menganggu dan mengeruhkannya. Sedangkan, amanah merupakan sesuatu yang disertakan kepada pihak lain disertai dengan rasa aman dari pemberiannya karena kepercayaannya bahwa apa yang diamankan akan terpelihara dengan baik $^{14}$.

Keluarga merupakan lembaga sosial yang paling dasar untuk mencetak kualitas manusia. Sampai saat ini, masih menjadi keyakinan dan harapan bersama bahwa keluarga senantiasa dapat diandalkan sebagai lembaga ketahana moral atau akhlak al karimah dalam konteks bermasyarakat, bahkan baik buruknya generasi suatu bangsa, ditentukan pula oleh

\footnotetext{
${ }^{11}$ Mufidah Cholil, Paradigma Gender, Malang: Bayu Media, 2004, Hal 75-76

${ }^{12}$ Mufidah Cholil, Paradigma Gender, Malang: Bayu Media, 2004, Hal 76

${ }^{13}$ Mufidah Cholil, Paradigma Gender, Malang: Bayu Media, 2004, Hal 73

${ }^{14}$ Hasbi As Shiddieqy, Tafsir Al Bayan Juz I, Bandung: Al Ma'arif, Hal.208-209
} 
pembentukan pribadi dalam keluarga. Di sinilah, keluarga memiliki peranan yang strategis untuk memenuhi harapan tersebut.

Secara sosiologis, Djudju Sudjana (1990) mengemukakan tujuh macam fungsi keluarga, yaitu berikut ini:

1. fungsi biologis bertujuan agar memperoleh keturunan dan dapat memelihara kehormatan serta martabat manusia sebagai makhluk yang berakal dan beradab;

2. fungsi edukatif, keluarga merupakan tempat pendidikan bagi semua anggotanya dimana orang tua memiliki peran yang cukup penting untuk membawa anak-anaknya menuju kedewasaannya jasmani dan rohani dalam dimensi kognitif, afektif, maupun psikomotor. Fungsi edukatif itu merupakan bentuk pemeliharaan hak dasar manusia dalam memeliahara dan mengembangkan potensi akalnya;

3. fungsi Religius, keluarga merupakan tempat penanaman nilai moral agama melalui pemahaman, penyadaran,dan praktik dalam kehidupan sehari-hari sehingga tercipta iklim keagamaan didalamnya;

4. fungsi Protektif, dimana keluarga menjadi tempat yang aman dari gangguan internal maupun eksternal keluarga dan untuk menangkal segala pengaruh negatif yang masuk didalamnya;

5. fungsi sosialisasi berkaitan dengan mempersiapkan anak menjadi anggota masyarakat yang baik, mampu memegang norma-norma kehidupan secara universal baik interrelasi dalam keluarga maupun dalam menyikapi masyarakat yang pluralistik lintas suku bangsa, ras, golongan, agama, budaya, bahasa, maupun jenis kelaminnya;

6. fungsi rekreatif yaitu menciptakan kondisi keluarga saling menghargai, menghormati, demokrasi, dan mampu mengakomodasi aspirasi masing-masing anggota keluarga sehingga tercipta hubungan harmonis, damai, kasih sayang, dan setiap anggota keluarga merasa "rumahku adalah surgaku”;

7. fungsi ekonomis, yaitu keluarga merupakan kesatuan ekonomis dimana keluarga memiliki aktivitas mencari nafkah, pembinaan usaha, perencanaan anggaran, pengelolaan, dan bagaimana dapat mempertanggungjawabkan kekayaan dan harta bendanya secara sosial maupun moral ${ }^{15}$.

\footnotetext{
${ }^{15}$ Mufidah Cholil, Paradigma Gender, Malang: Bayu Media, 2004, Hal 74
} 
Ditinjau dari keutuhuhan fungsi keluarga tersebut, jelaslah bahwa keluarga memiliki fungsi yang signifikan dalam pembentukan individu. Jika salah satu fungsi tidak berfungsi, maka akibatnya fatal termasuk munculnya istilah single parent dan yang menjadi korban tak lain adalah anak-anak.

Jika ditinjau dari segi psikologi, menurut Rogers tentang perempuan yang berstatus single parent berdasarkan teori kepribadian akan mengalami tingkat kesulitan adaptasi yang berbeda antara yang bekerja dan yang tidak bekerja serta antara yang ditinggal mati suaminya dengan yang akibat perceraian ${ }^{16}$. Masalah utama bagi perempuan yang ditinggal suami yaitu kehilangan sumber pencari nafkah utama dan hanya mengandalkan peninggalan suami semata jika ia tidak bekerja serta keharusan berfungsi sebagai orang tua tunggal dalam mengasuh anak-anak. Bagi perempuan yang bekerja, mereka harus dapat membagi waktu mereka antara pekerjaan dan anak-anak supaya anak-anak tidak tidak merasa kekurangan perhatian dan kasih sayang dari ibunya. Bagi perempuan yang bercerai dan bekerja, malah tanggung jawab mendidik anak-anak dan mencari nafkah rata-rata merupakan keharusan bagi perempuan. Para lelaki seolah-olah melepaskan tanggung jawab dari memberi nafkah kepada anak-anak dan juga mendidik mereka. Juga bagi perempuan yang bercerai dan tidak bekerja, mereka mengandalkan harta peninggalan orang tua atau harta gono gini bahkan kadang ada yang ikut sanak famili yang lebih mampu. Belum lagi, bagi kultur budaya masyarakat jawa yang memberi anggapan miring bahwa status janda berkonotasi jelek seperti perebut suami orang, tanpa suami tidak mampu menghidupi diri sendiri, kemana-mana pergi selalu dicurigai orang dan lain sebagainya.Tanpa disadari, semua faktor tersebut menyebabkan janda mengalami masalah secara psikologis yakni beban mental dan marginalisasi perempuan.

Selain perempuan yang berstatus single parent mengalami beban mental, menurut teori perkembangan moral Kohlberg, anak yang memiliki hubungan yang hangat dengan orang tuanya akan mengalami trauma yang hebat, bila itu terputus karena perceraian ${ }^{17}$. Disamping itu, mereka juga mempunyai problem psikologis lain dalam penyesuaian diri. Perceraian orang tua mengakibatkan sang anak mengalami hambatan perkembangan terutama perkembangan moral mereka. Banyak hal-hal negatif yang mereka lakukan misalnya minumminuman keras, merokok, melarikan diri dari rumah, pergaulan bebas, mencoba menggunakan narkoba, dan melakukan hal-hal lainnya yang dapat merugikan diri sendiri maupun orang lain.

\footnotetext{
${ }^{16}$ Zamralita, Psi. dan Henny E. Wirawan, M. Hum., Psi, Kemampuan Adaptasi Janda Dalam menjalankan Fungsinya Sebagai Orang Tua Tunggal, 2003, net.

${ }^{17}$ (Hurlock, Anak dalam Asuhan Orang Tua Tunggal, 1980/1994, net.
} 


\section{Pola asuh orang tua dan pengaruhnya terhadap perkembangan anak}

Pola asuh adalah merupakan suatu cara terbaik yang dapat ditempuh orang tua dalam mendidik anak sebagai perwujudan dari rasa tanggung jawab kepada anak di mana tanggung jawab untuk mendidik anak ini merupakan tanggung jawab primer. Karena anak merupakan buah dari buah kasih sayang yang diikat dalam tali perkawinan antara suami istri dalam suatu keluarga. Keluarga adalah satu elemen terkecil dalam masyarakat yang merupakan institusi sosial terpenting dan merupakan unit sosial yang utama melalui individu-individu disiapkan nilai-nilai hidup dan kebudayaan yang utama ${ }^{18}$.

Demikian peran keluarga menjadi penting untuk mendidik anak baik dari tinjauan agama, tinjauan social kemasyarakatan maupun tinjauan individu. Yang menjadi persoalan sekarang bukan lagi pentingnya pendidikan keluarga, melainkan bagaimana pendidikan keluarga dapat berlangsung dengan baik sehingga mampu menumbuhkan perkembangan kepribadian anak menjadi manusia dewasa yang memiliki sikap positif terhadap agama, kepribadian yang kuat dan mandiri, potensi jasmani dan rohani serta intelektual yang berkembang secara optimal. Cara mendidik ini menurut penulis dapat dilihat dalam tiga pola asuh orang tua terhadap anak yakni pola asuh yang demokratis, otokratik, dan permisif.

Menurut Kohn (1971), pola asuh merupakan sikap orang tua dalam berhubungan dengan anaknya, sikap ini dapat dilihat dari berbagai segi, antara lain dari cara orang tua memberikan peraturan kepada anak, cara memberikan hadiah, cara orang tua memberikan otoritas dan cara orang tua memberikan perhatian atau tanggapan terhadap keinginan anak ${ }^{19}$. Dengan demikian bahwa yang disebut denagn pola asuh orang tua adalah bagaimana cara mendididk orang tua kepada anak baik secara langsung maupun tidak langsung.

Cara mendidik secara langsung artinya bentuk-bentuk asuhan orang tua yang berkaitan dengan pembentukan kepribadian, kecerdasan, dan keterampilan yang dilakuakan secara sengaja baik berupa perintah, larangan, hukuman, dan penciptaan situasi maupun pemberian hadiah sebagai alat pendidikan. Dalam keadaan seperti ini yang diharapkan muncul dari anak adalah efek-instruksional yakni respon-respon anak terhadap aktifitas pendidikan itu.

Pendidikan secara tidak langsung adalah berupa contoh kehidupan sehari-hari baik tutur kata sampai kepada adaptasi kebiasaan dan pola hidup, hubungan antara keluarga,

\footnotetext{
${ }^{18}$ Hasan Langgulung, Manusia Dan Pendidikan, Jakarta, Pustaka Al-husna, 1986.

${ }^{19}$ Kohn,M.L. 1971,"Social Class and Parent Child Relationship: an interpretation", dalam M. Chabib Thoha, Kapita Selekta Pendidikan Islam, Pustaka Pelajar, 1988.
} 
masyarakat, hubungan suami istri. Semua ini secara tidak sengaja telah membentuk situasi di mana anak selalu bercermin terhadap kehidupan sehari-hari dari orang tuanya.

Hourlock (1973), mengemukakan ada tiga jenis pola asuh orang tua terhadap anaknya, yakni (1) pola asuh otoriter, (2) pola asuh demokratik, (3) pola asuh yang permisif ${ }^{20}$.

Pola asuh otoriter ditandai dengan dengan cara mengasuh anak dengan aturan-aturan yang ketat, sering kali memaksa anak untuk berprilaku seperti dirinya (orang tua), kebebasan untuk bertindak atas nama diri sendiri dibatasi. Anak jarang diajak berkomunikasi dan bertukar fikiran dengan orang tua, orang tua menganggap bahwa semua sikapnya sudah benar sehingga tidak perlu dipertimbangkan dengan anak. Pola asuh yang bersifat otoriter juga ditandai dengan penggunaan hukuman yang keras, lebih banyak menggunakan hukuman badan, anak juga diatur segala keperluan dengan segala aturan yang ketat dan masih diberlakukan meskipun sudah menginjak dewasa.

Menurut Prof. Dr. Abdul Aziz Al-Qussy, merupakan kewajiban orang tua untuk menolong anak dalam memenuhi kebutuhan hidup mereka, akan tetapi tidak boleh berlebihlebihan dalam menolong sehingga anak tidak kehilangan kemampuan untuk berdiri sendiri nanti $^{21}$. Lebih lanjut ia mengemukakan bahwa orang tua yang suka mencampuri urusan anak sampai masalah yang sekecil-kecilnya, misalnya mengatur jadwal yang perbuatan anaknya jam istirahat, cara membelanjakan uang, warna pakaian yang cocok memilihkan teman-teman untuk bermain, macam sekolah yang harus dimasuki. Anak yang dibesarkan dalam suasana seperti ini akan besar dengan sifat yang ragu-ragu, lemah kepribadian dan tidak sanggup mengambil keputusan tentang apa saja ${ }^{22}$.

Pola asuh kedua adalah pola asuh demokratis. Pola asuh ini ditandai dengan adanya pengakuan orang tua terhadap kemampuan anak, anak selalu diberi kesempatan untuk tidak bergantung kepada orang tua. Orang tua sedikit memberi kebebasan kepada anak untuk memilih apa yang terbaik bagi dirinya, anak didengarkan pendapatnya, dilibatkan dalam pembicaraan terutama yang menyangkut dengan kehidupan anak itu sendiri. Anak dilibatkan diberi kesempatan untuk berpartisipasi dalam mengatur hidupnya.

Namun menurut Prof.Dr.Abdul Aziz Al-Qussy, tidak semua orang tua harus mentolerir terhadap anak, dalam hal-hal tertentu orang tua perlu ikut campur tangan, misalnya: (1) dalam keadaan membahayakan hidupnya atau kesehatan anak, (2) hal-hal yang

\footnotetext{
${ }^{20}$ Hurlock, E.B, Adolescent Development, Tokyo, McGraw Hill, Inc, 1973

${ }^{21}$ Abdul Aziz Al-Qussy, Pokok-Pokok Mental/Jiwa, Ter. Dr. Zakiyah Darajat, Jakarta, Bulan Bintang, 1975, Hal. 220

${ }_{22}^{2}$ Abdul Aziz Al-Qussy, Pokok-Pokok Mental/Jiwa, Ter. Dr. Zakiyah Darajat, Jakarta, Bulan Bintang, 1975, Hal. 225
} 
terlarang bagi anak dan tidak tampak alasan-alasan yang lahir, (3) permainan yang menyenangkan bagi anak, tetapi menyebabkan keruhnya suasana yang menganggu ketenangan umum.

Demikian pula kepada hal-hal yang sangat prinsip sifatnya mengenai pilihan agama, pilihan nilai hidup yang bersifat universal dan absolut, orang tua dapat memaksakan kehendaknya kepada anak, karena anak belum memiliki wawasan yang luas dan cukup mengenai hal itu. Karena itu tidak semua materi pendidikan agama harus seluruhnya diajarkan secara demokratik kepada anak. Menurut kisah Lukman sebagaimana disebutkan dalam alqur'an, nampak bahwa pendidikan aqidah islamiyah tidak harus disajikan secara demokratis, melainkan secara dogmatis.

Pola asuh ketiga adalah pola asuh permisif. Pola asuh ini ditandai dengan cara orang tua mendididk anak secara bebas, anak dianggap sebagai orang dewasa/muda, ia diberi kelonggaran seluas-luasnya untuk melakukan apa saja yang dikehendaki. Kontrol orang tua terhadap anak sangat lemah, juga tidak memberikan bimbingan yang cukup berarti bagi anak. Semua apa yang telah dilakukan oleh anak adalah benar dan tidak perlu mendapatkan teguran, arahan dan bimbingan.

Cara mendidik yang demikian ternyata dapat diterangkan kepada orang dewasa yang sudah matang pemikirannya, tetapi tidak sesuai jika diterapkan kepada anak-anak remaja. Apabila diterapkan untuk pendidikan agama, banyak hal yang harus disampaikan secara bijaksana.

\section{E. Pengaruh pola asuh bagi anak dalam asuhan orang tua tunggal}

Penulis di sini mengejawantahkan hasil wawancara selama penelitian 20 hari di Pasuruan terhitung dari 3 Agustus 2007 sampai 23 Agustus 2007 dengan berdasarkan teori kepribadian $^{23}$. Menurut Rogers, ada empat kriteria perempuan yang mengalami tingkat kesulitan adaptasi yang berbeda ketika berpisah dengan suaminya yaitu: (1) ditinggal mati suami dan tidak bekerja (2) ditinggal mati suami dan bekerja (3) bercerai dan tidak bekerja (4) bercerai dan bekerja ${ }^{24}$. Di sini penulis menggunakan empat responden perempuan yang berstatus single parent yang mempunyai empat kriteria di atas.

Hasil wawancara dengan empat responden berikut dibawah ini:

\section{(1) Kasus single parent ditinggal mati suami dan tidak bekerja}

\footnotetext{
${ }^{23}$ Penelitian yang dilakukan penulis di Pasuruan selama 20 hari terhitung 3-23 Agustus 2007

${ }^{24}$ Zamralita, Psi. dan Henny E. Wirawan, M. Hum., Psi, Kemampuan Adaptasi Janda Dalam menjalankan Fungsinya Sebagai Orang Tua Tunggal, 2003, net.
} 
Ibu yang berusia 45 tahun ini bernama Ibu Azizah (nama samaran). Beliau telah berumah tangga 25 tahun dan sudah di karuniai 2 anak, beliau termasuk kategori ditinggal mati suami dan tidak bekerja Berikut wawancara yang diambil tanggal 3 Agustus 2007:

Sebut saja (IA) untuk Ibu Azizah dan (IR) untuk Iro (nama panggilan penulis)

IR : Sudah berapa lama Bu, Bapak meninggal? Dan profesi Bapak apa?

IA : Sudah 10 tahun meninggal karena sakit, profesinya sebagai petani.

IR : Kira-kira setelah Bapak meninggal, apa yang Ibu lakukan untuk menopang kebutuhan anak-anak?

IA : Ya.......cukup mengandalkan sawah....kalau dulu suami saya ke sawah...sekarang saya dibantu anak pertama dan adik-adik saya ngurus sawah dan ....mau gimana lagi ........yang penting sekeluarga bisa makan terutama untuk keperluan biaya sekolah anak saya yang nomer dua yang masih di bangku sekolah kalau kakaknya sudah lulus Aliyah.

IR : Berat nggak Bu....menjadi orang tua tunggal?

IA : Ya tentu mbak.......saya harus mikir sendiri semua......tapi saya kembalikan semuanya ke Allah semua ini kan sudah kehendak-Nya........tapi untung anak saya yang pertama mengerti sekali untuk bantu saya....setelah mondok......ngurus sawah bapaknya dan ngajar di pondok.......untuk biaya adiknya. Anak-anak saya nurut dan ngerti kok.......tahu kalau ibunya ini lagi susah......

IR : Apa adiknya mondok juga Bu?

IA : Ya...dulu........ bapaknya..... sejak kecil mereka sudah ditanamkan agama dan mengarahkan ke pondok tapi juga nggak maksa ...terserah anaknya........biar belajar mandiri dan ngerti agama Alhamdulillah........mereka nurut apa kata orang tua.......

IR : Apa Ibu dan Bapak hanya menginginkan anaknya pintar agama saja di pondok?

IA : Oh....nggak.......kalau kakaknya memang memilih pendidikan agama di pondok.......tapi adiknya sekolah STM tapi pulangnya di pondok.......katanya biar dapat umum dan agama

IR : Maaf sebelumnya, ada nggak Bu keinginan menikah lagi?

IA : Aduh..........hidup saya sekarang hanya untuk anak-anak saya saja jeng.......

Menurut hasil analisa penulis, Ibu Azizah sebagai orang tua tunggal menerapkan pola asuh demokrasi di mana anak diberi kebebasan untuk memilih apa yang terbaik bagi dirinya, anak didengarkan pendapatnya, anak diberi kesempatan untuk mengembangkan kontrol internalnya sehingga sedikit demi sedikit berlatih untuk bertanggung jawab kepada dirinya sendiri tidak selalu bergantung kepada orang tuanya. Terutama bagi anaknya yang 
pertama sudah mulai dilibatkan dalam pembicaraan menyangkut kondisi keuangan keluarga. Di sini, keterbukaan antara anak dan orang tua selalu terjalin dengan kuat karena adanya pengakuan orang tua tehadap kemampuan anak. Selain itu, beban hidup dan mental bagi perempuan berstatus single parent masih bisa diatasi karena religiusitas telah tertanam pada dirinya sendiri dan kedua anaknya sejak awal dan optimalnya tujuh fungsi keluarga sehingga seberat apapun resiko dalam menghadapi beban hidup terasa ringan. Terbukti kedua anaknya amat berbakti kepada kedua orang tua. Ditinjau dari perspektif gender, Ibu yang satu ini sudah mampu membuktikan sebaga orang tua tunggal walaupun tanpa suami di sisinya ia berhasil membawa anak-anaknya menuju prestasi dan menfasilitasi basic education dengan mengoptimalkan tujuh fungsi keluarga meskipun dalam keluarga yang tidak utuh.

\section{(2) Kasus single parent ditinggal mati suami dan bekerja}

Ibu yang berusia 26 tahun ini bernama Ibu Nanik (nama samaran). Beliau telah berumah tangga 5 tahun dan sudah di karuniai 1 anak, beliau termasuk kategori ditinggal mati suami dan bekerja. Beliau berprofesi sebagai pembantu rumah tangga. Berikut wawancara yang diambil tanggal 15 Agustus 2007:

Sebut saja (IN) untuk Ibu Nanik dan (IR) untuk Iro (nama panggilan penulis)

IR : Sejak kapan Bu, anda bekerja?

IN : Sebelum menikah.........saya sudah bekerja.......kalau dulu bantu-bantu suami..kalau sekarang..........ya...nyari buat anak

IR : Suaminya dulu kerja apa $\mathrm{Bu}$ ?

IN : Sopir angkot.....setelah saya melahirkan anak saya...... dia udah meninggal.

IR : Kira-kira cukup nggak Bu..... penghasilan anda?

IN : Ya ...nggak cukup mbak......kalau jadi pembantu rumah tangga di satu rumah.....sorenya saya ambil pakaian-pakaina kotor milik beberapa tetangga saya.untuk saya cuci malemnya sekaligus siangnya disetrika..........lumayan nambah-nambah buat beli susu anak saya... kadang-kadang juga saya masih terima bordir baju.....kalau ada pesanan

IR : Berarti kerepotan juga nih..........antara kerja dan ngurus anak!

IN : Ya mbak .....kebanyakan waktu saya untuk kerja........anak saya titipkan ke mbahnya.........paling-paling kalau menjelang maghrib saya ambil......ya tinggal capeknya .......saya cuma pasrah ke mbahnya .........tapi sekarang sudah pintar lho ........kan udah masuk TK.........tapi lumayan manja......minta apa saja saya belikan karena bagi saya biarpun nggak ada Bapaknya saya masih bisa kok 
memenuhi kebutuhannya...jangan sampai dia kekurangan......kasihan mbak mulai dari bayi dua bulan udah nggak lihat Bapaknya.........

IR : Tapi apa nantinya nggak keterusan manjanya buat anak Ibu ?

IN : Ya......nanti diurus nanti...pusing mbak nyari buat makan sehari-hari aja .......bikin stress........

IR : Ada rencana mau nikah lagi Bu?

IN : Ya ada sih.......wong saya masih muda...kasihan anak saya mbak butuh seorang Bapak ...nggak enak juga jadi omongan orang katanya janda muda itu perebut suami orang........lagian kalau saya punya suami lagi saya kan ada yang Bantu nyari uang.....

Ibu Nanik disini menerapkan pola permisif di mana beliau memanjakan anak dengan menuruti semua keinginannya dengan alasan kasih sayang. Kasih sayang tidak harus dengan memanjakan ini malah berdampak buruk karena kelak dewasa ia tidak akan mampu berdiri sendiri hanya bergantung orang tua dan apapun keinginannya harus dituruti. Kontrol orang tua terhadap anak sangat lemah juga tidak memberikan bimbingan yang berarti bagi anak karena ia lebih sibuk bekerja dan hanya pasrah kepada nenek sang anak ketika ditinggal bekerja. Beban hidup dan mental dipikul Ibu Nanik cukup membuatnya stress karena penghasilannya yang kecil dan tidak memiliki keahlian. Memang sungguh dilematis dalam hal ini, tapi dalam perspektif gender kita bisa melihat ada sisi positif dan negative. Pada sisi positif, perempuan dengan sosok Ibu Nanik telah mampu berusaha berperan ganda sebagai ibu dan pencaeri nafkah sedangkan pada sisi negatif, peran orang tua dalam menfasilitasi basic education masih belum maksimal Karen dari tujuh fungsi keluarga hanya beberapa saja yang berfungsi.

\section{(3) Kasus single parent bercerai dan tidak bekerja}

Ibu yang berusia 55 tahun ini bernama Ibu Muflikhah (nama samaran). Beliau telah berumah tangga 35 tahun dan sudah di karuniai 7 anak, beliau termasuk kategori bercerai dan tidak bekerja. Berikut wawancara yang diambil tanggal 18 Agustus 2007:

Sebut saja (IM) untuk Ibu Muflikhah dan (IR) untuk Iro (nama panggilan penulis)

IR : Sudah lama Bu anda bercerai?

IM : Sudah 15 tahun yang lalu......daripada makan hati....mending pisah begini....

IR : Sudah bekerja semua anaknya, Bu?

IM : Ya.......ada yang ikut suaminya ...ada yang bekerja........baru yang paling bungsu belum menikah tapi sudah bekerja di pabrik........

IR : Kira-kira anak-anak tahu nggak $\mathrm{Bu}$........apa penyebab perceraian Ibu? 
IM : Ya tahulah.......kelakuan Bapaknya kaya apa.......mereka kan udah dewasa....malah mereka nggak rela saya....mikir terus.....buat apa dipertahankan kalua Bapaknya abis insyaf ...begitu lagi...capek mikirnya.......suami saya suka selingkuh......

IR : Apa efek perceraian Ibu bagi anak-anak?

IM : Sejak kecil mereka sebenarnya sering mendengar saya bertengkar dengan suamiku dulu.........dia nggak bisa jadi contoh yang baik bagi kami........jadi mereka benci banget ama Bapaknya.......mereka selalu melawan apa kata Bapaknya......terutama anak perempuan saya yang paling bungsu jadi takut menikah lantaran trauma dengan kelakuan Bapaknya.......

IR : Bagaimana cara Ibu mendidik anak selama menjadi orang tua tunggal?

IM : Sebelum saya bercerai, keenam anak saya sudah bekerja dan berumah tangga, dulu waktu belum cerai Bapaknya nggak pernah mikir anak-anak mau disekolahkan dimana? SPP sudah bayar apa belum? Dia sibuk dengan pacar-pacarnya........ya saya mikir sendiri........anak saya ada yang putus sekolah ada yang sampai SMA....nggak ada biaya. Belum lagi, kalau dulu anak yang nomer tiga tuh.......ikut-ikutan pakai narkoba lantaran stress mikirin Bapaknya.........

IR : Kebutuhan sehari-hari gimana?

IM : Dari anak-anak saya.......wong saya nggak bekerja......saya sebenarnya dari dulu mau nikah lagi........ juga nggak boleh.......Ya.....mereka yang harus menuhin kebutuhan saya.......setiap bulannya anak-anak saya haruskan patungan mencukupi saya dan anak bungsu saya.

Sosok Ibu Muflikhah disini menerapkan pola permisif dan otoriter. Hal ini telah terbukti ketika anak-anaknya masih sekolah, dia membiarkan anaknya yang putus sekolah dan ada yang tamat sekolah seolah-olah sosok ibu tidak mau memperjuangkan bagaimana nasib pendidikan anak-anaknya atau dalam kata lain pasrah terhadap nasib ketidakmampuannya. Pada pola otoriter dia tunjukkan dengan menekan anak-anaknya untuk menbiayai hidupnya hanya karena dilarang menikah oleh anak-anaknya. Jika ditinjau dari perspektif gender, relasi gender dan tujuh fungsi keluarga gagal diterapkan dalam keluarga mereka karena orang tua mempunyai sikap egois, kepasrahan, dan ketidakpedulian terhadap anak mereka nampak ironis sekali. Dalam kata lain, keluarga sebagai basic education tidak berfungsi sebagaiman mestinya dalam keluarga Ibu Muflikhah.Hal ini dikarenakan oleh beban hidup dan mental tidak dapat diatasi oleh suami istri tersebut sehingga munculah setumpuk 
persoalan di mana satu belum selesai muncul persoalan yang lain dan pada akhirnya perceraian juga tidak menyelesaikan setumpuk persoalan tersebut.

\section{(4) Kasus single parent bercerai dan bekerja}

Ibu yang berusia 35 tahun ini bernama Ibu Tina (nama samaran). Beliau telah berumah tangga 7 tahun dan sudah di karuniai 3 anak, beliau termasuk kategori bercerai dan bekerja. Beliau berprofesi sebagai Perawat disalah satu rumah sakit di Pasuruan. Berikut wawancara yang diambil tanggal 23 Agustus 2007:

Sebut saja (IT) untuk Ibu Tina dan (IR) untuk Iro (nama panggilan penulis)

IR : Sudaha lama Bu bekerja di Rumah Sakit?

IT : Ya.......seja sebelu menikah....sampai saat ini saya hidup sendiri

IR : Sejak kapan Ibu hidup sendiri?

IT : 7 tahun yang lalu....

IR : Kira-kira efek apa yang paling kelihatan bagi perkembangan anak-anak akibat perceraian?

IT : figure seorang ayah yang mereka butuhkan ...........anak-anak saya masih kecilkecil.........Ayahnya dulu seorang tentara......yang ketahuan nikah lagi..ya ....saya minta cerai......siapa yang mau dimadu.......tapi saya berusaha menutupi dari ketiga anak saya apa faktor perceraian kami....nggak baik buat perkembangan anak.........

IR : Kalau mereka udah dewasa nanti gimana?

IT : Tetap saya rahasiakan...ya ...baru kalau sangat terpaksa sekali ...baru saya ceritakan...

IR : Tips Ibu untuk mendidik anak bagaimana?

IT : Sedini mungkin saya tanamkan boleh punya cita-cita apa saja asalkan jangan jadi tentara...lantaran saya masih trauma dengan suami saya......kadang saya takut karena ketiga anak saya laki-laki dan mereka ada kecenderungan menjadi tentara....saya tidak pernah membelikan mainan pistol ........atau saya tidak pernah membiarkan mereka nonton film peperangan.........pokoknya anak saya nanti jangan sampai masuk Akademi Militer..........ke Perguruan Tinggi saja.......atau kalau perlu jadi Dokter saja soalnya saya dulu tidak kesampaian jadi Dokter Cuma Perawat..........

IR : Kerepotan nggak Bu ngurus anak-anak?

IT : Ya ..jelas mbak kalau saya kerja saya titipkan ke Ibu saya, ..........saya usahakan tetap membagi waktu untuk memantau prestasi anak-anak jangan sampai mereka kebanyakan main ...tugas mereka cuma belajar.......biar jadi Dokter........ 
IR : Cukup nggak penghasilan Ibu?

IT : Alhamdulillah cukup karena saya juga punya kerjaan sampingan menerima pesanan kue.

Menurut hasil penelitian ini, Ibu Tina menerapkan pola otoriter dimana mengasuh anak dengan aturan-aturan yang ketat, sering kali memaksa anak untuk berprilaku sesuai dengan keinginannya misalnya menjadi dokter, kebebasan untuk bertindak atas nama diri sendiri dibatasi. Anak jarang diajak komunikasi dan bertukar fikiran dengan orang tua, orang tua menganggap bahwa semua sikapnya sudah benar sehingga tidak perlu dipertimbangkan dengan anak. Jika ditinjau dari perspektif gender, ada sisi positif dan negatifnya. Pada sisi positif, sosok Ibu Tina mampu berperan ganda sebagai Ibu dan pencari nafkah sedangkan pada sisi negatifnya, relasi gender tidak berfungsi sebagaimana mestinya dan pada akhirnya perceraian menjadi solusi mereka (suami istri). Selain itu, dari tujuh fungsi keluarga hanya beberapa saja yang berfungsi sehingga keluarga sebagai sarana basic education masih belum optimal karena sang ibu terlalu memaksakan kehendaknya akibat trauma dengan masa lalunya. Dalam kata lain, ibu tersebut menerapkan pola asuh otoriter kepada anaknya.

\section{F. Kesimpulan}

Pendidikan dalam keluarga merupakan bagian dari jalur pendidikan luar sekolah yang diselenggarakan di dalam keluarga di mana memberikan keyakinan agama, nilai budaya, nilai moral dan keterampilan. Dalam hal ini, pendidikan dalam keluarga merupakan pendidikan utama dan pertama, artinya bahwa pendidikan pertama kali dan yang memberikan arti terhadap perkembangan dan prestasi anak adalah pendidikan keluarga. Mengingat demikian penting dan strategisnya pendidikan dalam keluarga, maka orang tua bertanggung jawab sepenuhnya terhadap anaknya di mana harus semaksimal mungkin mendidik anaknya menuju pertumbuhan dan perkembangan fitrahnya. Kesalahan dalam pendidikan anak tersebut akan berakibat fatal, yakni si anak dapat menyimpang dari fitrah (nature) dan potensi kebaikannya berubah menjadi manusia yang berkualitas rendah.

Terdapat tiga pola asuh orang tua terhadap anaknya, yaitu pola asuh demokratis, otoriter, dan permisif. Berdasarkan hasil penelitian penulis diantara ketiga pola asuh tersebut yang dianggap sebagai cara mendidik yang baik adalah pola asuh demokratis, tetapi tetap mempertahankan prinsip-prinsip nilai yang universal dan absolut terutama yang berkaitan dengan agama islam. Pola otoriter layak dilakukan jika terkait dengan persoalan aqidah dan ibadah yang bersifat dogmatis serta hal-hal yang dianggap membahayakan bagi si anak. Sementara pola permisif juga dapat diterapkan pada anak usia dewasa. 
Selain itu, berdasarkan hasil penelitian menunjukkan adanya korelasi antara sikap dan perkembangan anak dengan pola asuh yang diterapkan orang tuanya Di Indonesia, pola asuh yang digunakan kebanyakan menggunakan pola ganda, yakni dalam memberikan kepuasan emosional orang tua bersifat permisif atau menuruti kehendak anak, dan biasanya hal ini menyebabkan anak manja. Pada pola kedua, ada yang menelantarkan anak atau kurang memperhatikan anak bahkan ada yang membatasi keinginan anak (otoriter) dengan berbagai macam sebab. Pola asuh yang demikian itu akan berakibat lemahnya prestasi dan bahkan moral si anak yang pada akhirnya akan menyebabkan rusaknya bangunan moral masyarakat dan negara.

Lebih lanjut, berdasarkan penelitian juga, terjadinya perempuan berstatus single parent dikarenakan oleh dua faktor yaitu ditinggal mati suami dan perceraian. Jika ditinggal mati itu suami, maka itu termasuk sunnatullah. Tapi jika akibat perceraian, maka relasi gender dan tujuh fungsi keluarga masih belum optimal diterapkan sehingga keluarga sebagai sarana basic education bagi pendidikan anak juga belum optimal hasilnya. Oleh karena itu, kesadaran orang tua (menerapkan pola asuh dan tujuh fungsi keluarga merupakan variabel yang sangat berpengaruh bagi sikap dan perkembangan anak. Kesimpulannya, baik bagi perempuan yang berstatus single parent yang ditingggal mati suami maupun perceraian hendaknya mencamkan bahwa kesadaran orang tua (menerapkan pola asuh) dan tujuh fungsi keluarga merupakan variabel yang sangat berpengaruh bagi sikap dan perkembangan anak sehingga prestasi anak tidak hanya ditentukan dalam keluarga yang utuh tapi single parent juga mampu menfasilitasi basic education bagi anak. Persoalan beban mental dan hidup seharusnya bukan menjadi alasan utama yang menyebabkan prestasi anak menurun tapi diupayakan bagaimana memotivasi dan memberi pengertian terhadap anak dengan kondisi dan situasi yang saat ini terjadi sehingga anak tidak menjadi korban. 


\section{DAFTAR PUSTAKA}

Ahmad tafsir, Ilmu Pendidikan Dalam Perspektif Islam, Remaja Rosdakarya, Bandung, cet.ii, 1994

Al-Qussy, Abdul Aziz, Pokok-Pokok Kesehatan Mental/Jiwa, Terj. Dr. Zakiyah Darajat, Jakarta, Bulan Bintang, 1975.

Fazlur Rahman, Islam, Terj. Ahsin Muhammad, bandung, Pustaka, 1984.

Hasan Langgulung, Manusia dan Pendidikan, Jakarta, Pustaka Al-Husna

Hurlock, E.B, Adolescent Development, Tokyo, McGraw Hill, Inc, 1973.

Kohn, M.L, 1971, "Social Class and Present Child Relationship: an interpretation", dalam M.ChabibThoha, Kapita Selekta Pendidikan Islam, Pustaka Pelajar, 1988.

Mastuhu, Dinamika Sistem Pendidikan Pesantren, Jakarta, INIS, 1994

Mufidah Ch, 2004, Paradigma Gender, Malang:Bayu Media

Muhaimin, dkk. Pemikiran Pendidikan Islam, Trigenda Karya, Bandung, 1993.

Soelaiman Joesoef, Pendidikan Luar Sekolah, CV. Usaha Nasional, Surabaya, 1979

Wahyu, Wawasan Ilmu Sosial Dasar, Surabaya, Usaha Nasional, 1986.

www.duniaesai.com/panduan1.htm

www.telaga.org/audio.php?orangtua_anak.htm 